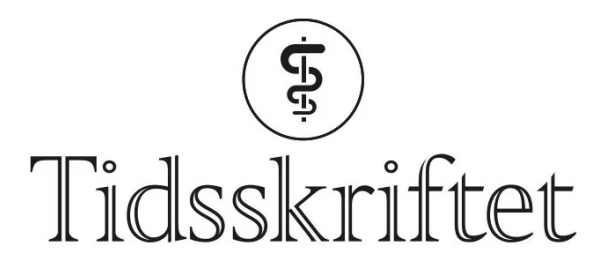

DEN NORSKE LEGEFORENING

\title{
Hofteproteser i Norge 1989-2008
}

\author{
ORIGINALARTIKKEL
}

\section{BIRGITTE ESPEHAUG}

Birgitte Espehaug (f. 1962)

er dr. philos. Hun er statistiker ved Nasjonalt register for leddproteser, Haukeland universitetssykehus og førsteamanuensis ved Høgskolen i Bergen.

Oppgitte interessekonflikter: Har holdt foredrag som har gitt Nasjonalt register for leddproteser honorar av firmaet Stryker.

Email: birgitte.espehaug@helse-bergen.no

Nasjonalt register for leddproteser

Ortopedisk klinikk

Haukeland universitetssykehus

og

Høgskolen i Bergen

\section{OVE FURNES}

Ove Furnes (f. 1960)

er dr.med. og spesialist i ortopedisk kirurgi. Han er klinikkoverlege ved Ortopedisk klinikk og Nasjonalt register for leddproteser, Haukeland universitetssykehus og professor ved Universitetet i Bergen. Har vært engasjert i drift og forskning i Nasjonalt register for leddproteser siden 1992, også som leder, og er president i International Society of Arthroplasty Registries.

Oppgitte interessekonflikter: Har holdt foredrag som har gitt Nasjonalt register for leddproteser honorar av firmaet Stryker, samt har mottatt honorar for foredrag fra Ortomedic. Haukeland universitetssykehus har mottatt forskningsstøtte til ett prosjekt der han er forskningsleder, med felles finansiering fra Helse Vest og firmaene Ortomedic og Smith \& Nephew.

Nasjonalt register for leddproteser

Haukeland universitetssykehus

og

Institutt for kirurgiske fag

Universitetet i Bergen

\section{LARS BIRGER ENGESATER}

Lars Birger Engsæter (f. 1948)

er spesialist i generell kirurgi og ortopedisk kirurgi. Han er professor ved Universitetet i Bergen og seksjonsoverlege ved Ortopedisk avdeling, Haukeland universitetssykehus.

Ingen oppgitte interessekonflikter.

Nasjonalt register for leddproteser

Haukeland universitetssykehus

og

Institutt for kirurgiske fag

Universitetet i Bergen

\section{LEIF IVAR HAVELIN}

Leiv Ivar Havelin (f. 1949) 
er dr.med. og spesialist i ortopedisk kirurgi. Han er overlege ved Ortopedisk avdeling og Nasjonalt register for leddproteser, Haukeland universitetssykehus og professor ved Universitetet i Bergen. han har vært engasjert i drift og forskning i Nasjonalt register for leddproteser siden 1987 og er leder av styringsgruppen for Nasjonalt kompetansesenter for leddproteser.

Oppgitte interessekonflikter: Har holdt foredrag som har gitt Nasjonalt register for leddproteser honorar av firmaet Stryker.

Nasjonalt register for leddproteser

Haukeland universitetssykehus

og

Institutt for kirurgiske fag

Universitetet i Bergen

\section{BAKGRUNN.}

Regionale forskjeller i forekomst av primære hofteproteseoperasjoner i Norge er lite undersøkt. Vi ønsket derfor å sammenlikne forekomst etter bosted i fylker og regionale helseforetak.

\section{MATERIALE OG METODE.}

Studien inkluderte primære hofteproteseoperasjoner som ble utført 1989-20o8 og meldt til Nasjonalt register for leddproteser. Årlig kjønns- og aldersstandardisert rate ble beregnet, og Poisson-regresjon ble benyttet for å sammenlikne forekomst mellom grupper. Informasjon om sist registrerte bosted per 31.12. 2008 ble innhentet fra Folkeregisteret.

\section{RESULTATER}

Vi observerte en økning i forekomst av hofteproteseoperasjoner fra 109 per 100 ooo innbyggere i 1991-95 til 140 i 2006-o8 (rateratio $(R R)=1,28$ ). For operasjoner utført på grunn av idiopatisk coxartrose var tendensen sterkere $(R R=1,46)$. $\emptyset \mathrm{kt}$ forekomst av hofteproteseoperasjoner var tydelig innen alle helseregioner og fylker. Vi fant forskjeller mellom bostedsområder, men disse ble mindre over tid. I 2006-o8 hadde Helse Midt-Norge 152 operasjoner per 100 ooo innbyggere. Forekomsten var statistisk signifikant høyere enn i alle andre regionale helseforetak, unntatt Helse Sør. Lavest forekomst hadde Finnmark (116), og høyest forekomst hadde Aust-Agder (172).

\section{FORTOLKNING.}

Regionale forskjeller i dag er langt mindre enn tidlig i 1990-årene. Det kan diskuteres i hvilken grad sykehusdekning, operasjonskapasitet, varierende indikasjonsstilling eller genetiske og kulturelle ulikheter kan forklare de forskjeller som fortsatt finnes.

\section{Tabell}

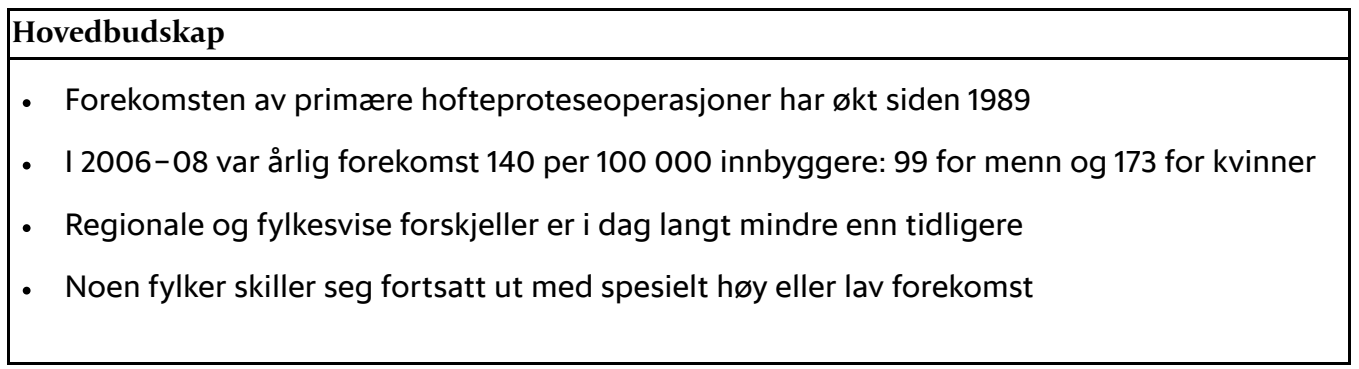


Hofteprotesekirurgi er i kostnad-nytte-analyser rangert som en av de mest vellykkede behandlinger innen medisinsk og kirurgisk behandling $(\underline{1}, \underline{2})$. Hofteprotesekirurgi for artrosepasienter er vist å gi betydelig reduksjon av smerte og forbedret funksjon samt lavere kostnader enn ved annen behandling (3). Forekomsten av primære totale hofteproteser er likevel svært forskjellig i ulike land (4). Disse kan imidlertid være vanskelige å sammenlikne, siden de ofte er fra ulike tidsperioder og er beregnet uten at det er tatt hensyn til befolkningsmessige forskjeller. Det er tidligere rapportert at hofteprotesekirurgi på grunn av revmatiske lidelser er avtakende (5)-( $\underline{8})$, noe som kan skyldes mer effektive medikamenter. Totalt sett er forekomsten av hofteproteseoperasjoner i vestlige land likevel klart økende. Dette er dokumentert for alle nordiske land (9.), for

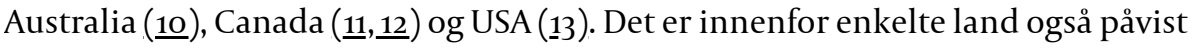
betydelige regionvise forskjeller i aldersstandardiserte rater (12,14)-(17.). I Norge er forekomsten av primær hofteprotesekirurgi innenfor ulike regioner ukjent. Formålet med denne studien var å undersøke om forekomst av primære totale hofteproteser varierte med bosted. Vi sammenliknet derfor forekomst av hofteproteseoperasjoner i befolkningen etter bosted fordelt på regionale helseforetak og bostedsfylke i årene 1989-2008. Vi ønsket også å fokusere på endringer i forekomst over tid.

\section{Materiale og metode}

Nasjonalt register for leddproteser ( $\underline{18}$ ) startet i september 1987 å registrere informasjon om primære hofteproteseoperasjoner og eventuelle revisjoner $(\mathbf{1 9}, \underline{20})$. Informasjon sendes til registeret på papirskjema av ortopediske kirurger ved alle sykehus i Norge som utfører denne type kirurgi. Sammenliknet med antall operasjoner meldt til Norsk pasientregister ble 97 \% av primære hofteproteseoperasjoner meldt til registeret i årene 1999-2002 (201). Registreringen dekket ikke alle sykehus før 1989. Vi inkluderte i denne studien derfor primære hofteproteseoperasjoner utført i perioden januar 1989- desember 2008, med unntak av operasjoner utført på pasienter uten kjent bosted $(n=37)$. Studien var basert på informasjon om hofteproteseoperasjoner meldt til leddproteseregisteret. Informasjon om sist registrerte bosted per 31.12. 2008 ble innhentet fra Folkeregisteret, og befolkningsdata fra Statistisk sentralbyrå (22).

\section{ANALYSER}

Årlig ujustert rate for primære totale hofteproteser for årene 1989-2008 og for tidsperiodene 1989-90, 1991-95, 1996-2000, 2001-05 og 2006-08 ble estimert som antall operasjoner dividert med middelfolkemengden (gjennomsnitt av folkemengden ved begynnelsen og utgangen av året) i Norge. Inndelingen er så langt det var mulig gjort i femårsintervaller for å gi anledning til sammenlikning med andre studier. Årlig alders- og kjønnsstandardisert rate ble estimert ved direkte standardisering (23) med kjønns- og aldersfordelingen (o-39, 40-49, 50-59, 6o-69, 70-79, 80+ år) i Norge i hele studieperioden som standardpopulasjon. Årlig rate for hver tidsperiode ble også beregnet for ulike diagnoser som kan føre til protesekirurgi, for de enkelte regionale helseforetak og fylker samt for undergrupper definert av kjønn og alder ved primæroperasjon. Selv om ulike land kan ha helt forskjellig aldersfordeling, vil et felles valg av standardpopulasjon likevel gi sammenliknbare tall for forekomst. Årlig aldersstandardisert rate ble derfor også funnet ut fra en beregnet europeisk standardpopulasjon (24). . Rateratio (RR)-verdier for endring i forekomst over tid og mellom geografiske områder ble estimert ved Poisson-regresjon med tidsperioden 1991-95 som referanse. I disse analysene ble det justert for kjønn og alder gruppert som angitt ovenfor.

P-verdier under o,05 ble ansett for statistisk signifikante. Analysene ble utført ved hjelp av programvaren SPSS 16.o (SPSS Inc., Chicago, IL).

\section{Resultater}


I studieperioden ble 112514 primære hofteproteseoperasjoner utført i Norge. Vi observerte en økning over tid i årlig alders- og kjønnsstandardisert forekomst av primære totale hofteproteser (fig 1), fra 109 operasjoner per 100 ooo innbyggere i 1991-95 til 140 i 2006-08 $(\mathrm{RR}=1,28 ; 95 \%$ konfidensintervall: 1,25-1,30) (e-tab 1). Økningen var sterkest $\mathrm{i}$ annen halvpart av 1990-årene og etter det har det bare vært mindre endringer (fig 1 ). Høyest forekomst ble observert i 2003 med 157 operasjoner per 100 ooo innbyggere. Forskjellen mellom standardisert og ujustert rate var liten gjennom hele tidsperioden (fig 1 ).

\section{E-tabell 1}

Kjønns- og aldersstandardisert forekomst ${ }^{1}$ for primære totale hofteproteser per 100 ooo innbyggere etter tidsperiode

\begin{tabular}{|c|c|c|c|c|c|c|c|}
\hline & $\begin{array}{c}\text { Antall } \\
\text { proteser }\end{array}$ & $\begin{array}{l}1989- \\
1990\end{array}$ & $\begin{array}{c}1991- \\
1995\end{array}$ & $\begin{array}{l}1996- \\
2000\end{array}$ & $\begin{array}{l}2001- \\
2005\end{array}$ & $\begin{array}{c}2006- \\
2008\end{array}$ & $\begin{array}{c}\mathrm{RR}^{2}(95 \% \mathrm{KI}) \\
2006-08 \mathrm{vs} . \\
1991-95\end{array}$ \\
\hline Totalt & 112514 & 116 & 109 & 121 & 143 & 140 & $\begin{array}{c}1,28(1,25- \\
1,30)\end{array}$ \\
\hline \multicolumn{8}{|l|}{ Kjønn } \\
\hline Menn & 34479 & 79 & 76 & 80 & 96 & 99 & $\begin{array}{c}1,30(1,26- \\
1,35)\end{array}$ \\
\hline Kvinner & 78035 & 146 & 137 & 154 & 181 & 173 & $\begin{array}{c}1,27(1,24- \\
1,30)\end{array}$ \\
\hline \multicolumn{8}{|l|}{ Alder } \\
\hline $0-39$ & 2056 & 4,3 & 4,1 & 4,2 & 4,2 & 4,4 & $\begin{array}{c}1,08(0,94- \\
1,24)\end{array}$ \\
\hline $40-49$ & 4438 & 36 & 33 & 32 & 38 & 42 & $1,27(1,16-1,39)$ \\
\hline $50-59$ & 13783 & 142 & 117 & 124 & 151 & 155 & $\begin{array}{c}1,33(1,25- \\
1,40)\end{array}$ \\
\hline $60-69$ & 31456 & 391 & 366 & 401 & 433 & 435 & $1,18(1,14-1,23)$ \\
\hline $70-79$ & 43921 & 602 & 576 & 632 & 786 & 758 & $\begin{array}{c}1,32(1,28- \\
1,36)\end{array}$ \\
\hline $80+$ & 16860 & 312 & 332 & 400 & 500 & 458 & $1,37(1,31-1,44)$ \\
\hline \multicolumn{8}{|l|}{ Diagnose $^{3}$} \\
\hline $\begin{array}{l}\text { Idiopatisk } \\
\text { coxartrose }\end{array}$ & 81510 & 77 & 74 & 85 & 109 & 109 & $\begin{array}{c}1,46(1,43- \\
1,50)\end{array}$ \\
\hline Revmatoid artritt & 3390 & 4,0 & 4,2 & 4,0 & 3,7 & 3,1 & $\begin{array}{c}0,74(0,66- \\
0,83)\end{array}$ \\
\hline $\begin{array}{l}\text { Sekvele fractura } \\
\text { colli femoralis }\end{array}$ & 11690 & 16 & 14 & 14 & 12 & 10 & $\begin{array}{c}0,70(0,66- \\
0,75)\end{array}$ \\
\hline Sekvele dysplasi & 8203 & 10 & 8,9 & 8,4 & 9,6 & 9,5 & $\begin{array}{c}1,05(0,98- \\
1,13)\end{array}$ \\
\hline $\begin{array}{l}\text { Sekvele dysplasi } \\
\text { m/luksasjon }\end{array}$ & 815 & 2,3 & 1,4 & 0,7 & 0,4 & 0,4 & $\begin{array}{c}0,31(0,23- \\
0,41)\end{array}$ \\
\hline $\begin{array}{l}\text { Sekvele Perthes } \\
\text { sykdom/epifyse }\end{array}$ & 1480 & 1,6 & 1,6 & 1,6 & 1,8 & 1,8 & $1,12(0,95-1,31)$ \\
\hline
\end{tabular}




\begin{tabular}{|c|c|c|c|c|c|c|c|}
\hline & $\begin{array}{c}\text { Antall } \\
\text { proteser }\end{array}$ & $\begin{array}{c}1989- \\
1990\end{array}$ & $\begin{array}{c}1991- \\
1995\end{array}$ & $\begin{array}{l}1996- \\
2000\end{array}$ & $\begin{array}{c}2001- \\
2005\end{array}$ & $\begin{array}{c}2006- \\
2008\end{array}$ & $\begin{array}{c}\mathrm{RR}^{2}(95 \% \mathrm{KI}) \\
2006-08 \mathrm{Vs} . \\
1991-95\end{array}$ \\
\hline $\begin{array}{l}\text { Bekhterevs } \\
\text { sykdom }\end{array}$ & 476 & 0,5 & 0,5 & 0,6 & 0,5 & 0,5 & $0,82(0,61-1,11)$ \\
\hline Fraktur & 1103 & 0,3 & 0,3 & 0,7 & 3,0 & 3,0 & $\begin{array}{c}9,60(7,44- \\
12,0)\end{array}$ \\
\hline Caputnekrose & 1597 & 0,6 & 0,9 & 1,5 & 3,6 & 3,6 & $\begin{array}{c}3,99(3,37- \\
4,17)\end{array}$ \\
\hline Annet & 2572 & 2,3 & 2,4 & 2,7 & 3,1 & 3,1 & $1,16(1,02-1,31)$ \\
\hline
\end{tabular}

[i] ${ }^{1}$ Kjønns- og aldersfordeling i Norge i 1989-20o8 som standard (når aktuelt) ${ }^{2}$ Rateratio (RR) justert for kjønn og alder (når aktuelt) ved Poisson-regresjon

${ }^{3}$ Mer enn én årsak kan være meldt til Nasjonalt register for leddproteser

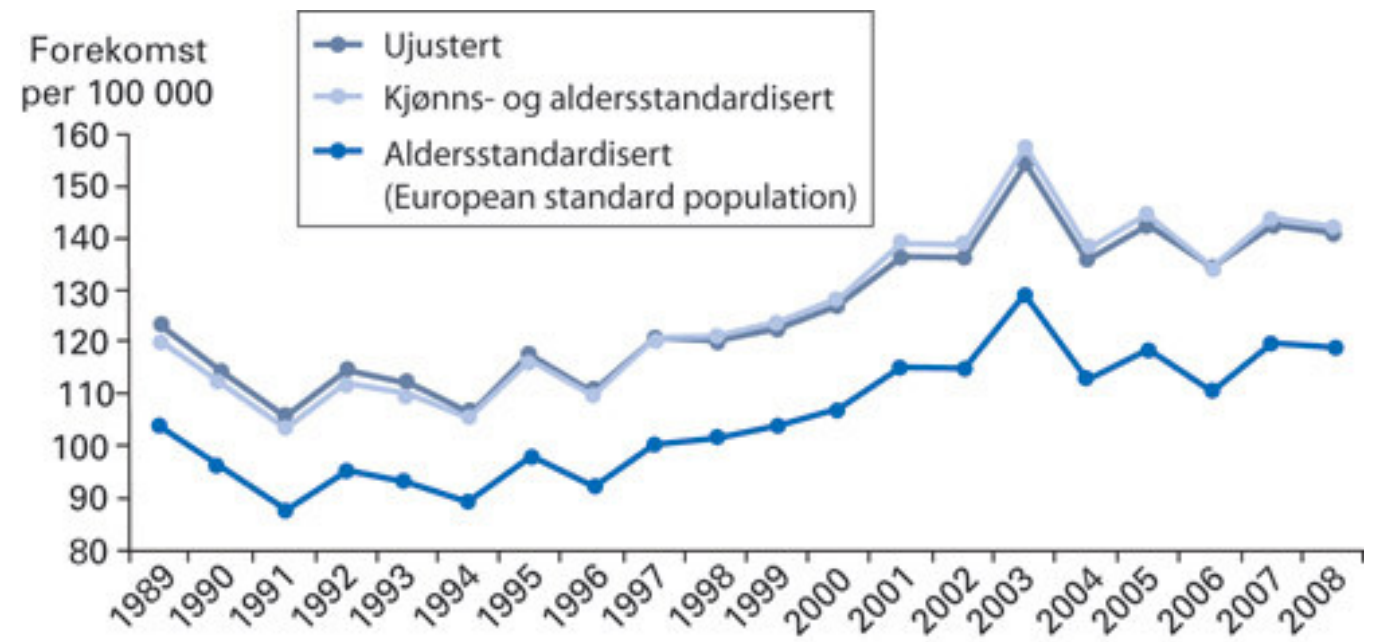

Figur 1 Forekomst for primære totale hofteproteser per 100 ooo innbyggere etter operasjonsår. Forekomst er gitt ujustert, standardisert etter kjønns- og aldersfordeling i Norge i 1989-2008 og standardisert etter aldersfordeling i Europa (European standard population, ESP)

Aldersjustert forekomst av hofteproteseoperasjoner var lavere for menn enn for kvinner, og var i siste periode lik 99 per 100 ooo menn og 173 for kvinner. Forekomsten av hofteproteseoperasjoner økte over tid for alle aldersgrupper over 40 år, men var minst tydelig i aldersgruppen 6o-69 år. Økningen i forekomst var sterkere for hofteproteser satt inn på grunn av idiopatisk coxartrose $(R R=1,46)$ enn den som ble observert for totalmaterialet (e-tab 1).

\section{BOSTEDSFYLKE OG REGIONALT HELSEFORETAK}

$\emptyset$ kningen i forekomst var tydelig innen alle regionale helseforetak og fylker (tab 2). Ved sammenlikning av forekomst i 1991-95 og 2006-o8 fant vi størst økning blant innbyggere i Helse Nord ( $R R=1,49 ; 95 \%$ KI 1,40-1,59). Helse Nord har likevel ganske konsistent hatt den laveste forekomsten gjennom hele studieperioden (fig 2). På fylkesnivå fant vi minst $\emptyset$ kning blant innbyggere i Rogaland $(R R=1,13 ; 1,05-1,21)$ og Telemark $(R R=1,13 ; 1,03-1,24)$ og størst økning i Nordland ( $R R=1,86 ; 1,70-2,04)$ (tab 2). 


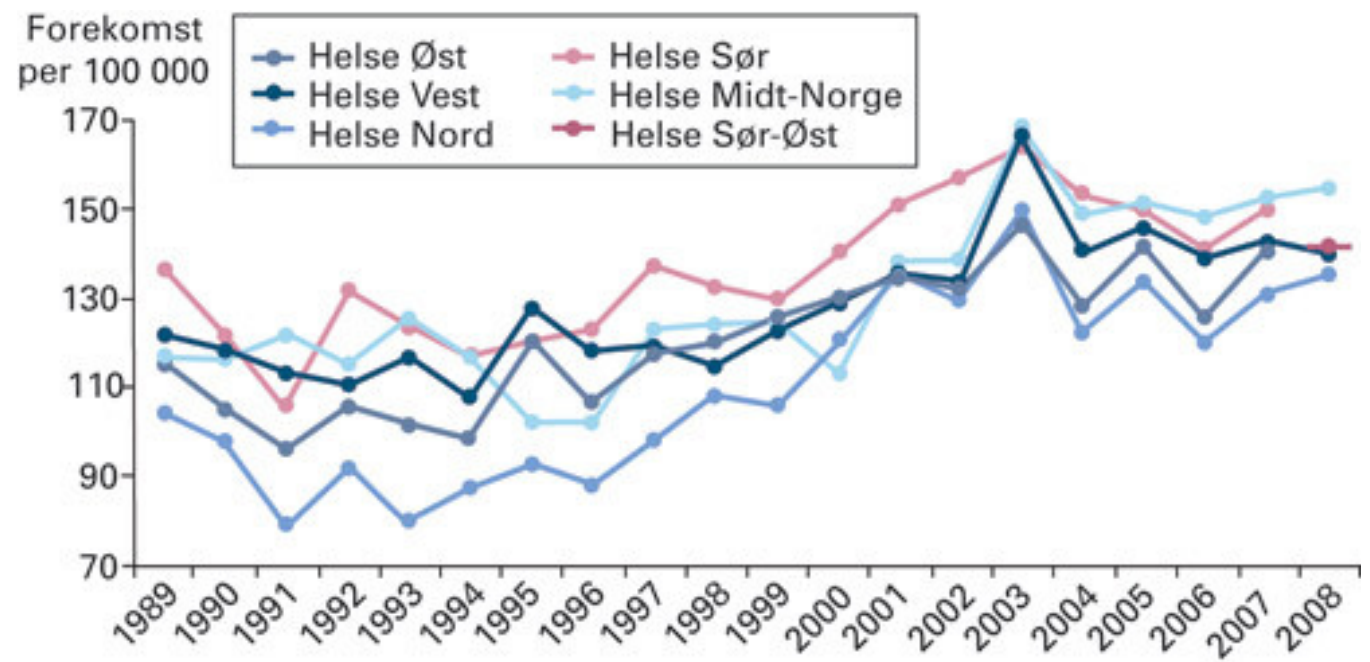

Figur 2 Forekomst for primære totale hofteproteser per 100 ooo innbyggere etter bosted i regionalt helseforetak og operasjonsår standardisert etter kjønns- og aldersfordeling i Norge i 1989-2008

\section{Tabell 2}

Kjønns- og aldersstandardisert forekomst ${ }^{1}$ for primære totale hofteproteser per 100 ooo innbyggere etter bosted og tidsperiode

\begin{tabular}{|c|c|c|c|c|c|c|c|}
\hline $\begin{array}{l}\text { Regionalt } \\
\text { helseforetak } \\
\text { Fylke }\end{array}$ & $\begin{array}{c}\text { Antall } \\
\text { proteser }\end{array}$ & $\begin{array}{c}1989- \\
1990\end{array}$ & 1991-1995 & $\begin{array}{c}1996- \\
2000\end{array}$ & $\begin{array}{c}2001- \\
2005\end{array}$ & 2006-2008 & $\begin{array}{c}\mathrm{RR}^{2}(95 \% \mathrm{KI}) \\
2006-08 \mathrm{vs} . \\
1991-95\end{array}$ \\
\hline Helse $\varnothing$ st $^{3}$ & 39125 & 111 & 104 & 120 & 137 & 134 & $\begin{array}{c}1,28(1,24- \\
1,32)\end{array}$ \\
\hline$\varnothing$ stfold & 6433 & 113 & 111 & 111 & 131 & 136 & $1,23(1,13-1,32)$ \\
\hline Akershus & 10220 & 107 & 105 & 127 & 140 & 133 & $1,24(1,17-1,32)$ \\
\hline Oslo & 10463 & 81 & 88 & 107 & 120 & 120 & $\begin{array}{c}1,34(1,26- \\
1,43)\end{array}$ \\
\hline Hedmark & 6355 & 144 & 120 & 138 & 158 & 162 & $\begin{array}{c}1,36(1,25- \\
1,47)\end{array}$ \\
\hline Oppland & 5654 & 154 & 117 & 130 & 152 & 135 & $\begin{array}{c}1,16(1,06- \\
1,27)\end{array}$ \\
\hline Helse Sør ${ }^{3}$ & 24678 & 129 & 120 & 132 & 155 & 147 & $1,23(1,18-1,28)$ \\
\hline Buskerud & 6612 & 132 & 115 & 127 & 155 & 148 & $1,26(1,17-1,37)$ \\
\hline Vestfold & 5770 & 114 & 11 & 132 & 142 & 145 & $\begin{array}{c}1,30(1,20- \\
1,42)\end{array}$ \\
\hline Telemark & 5153 & 128 & 127 & 133 & 164 & 144 & $1,13(1,03-1,24)$ \\
\hline Aust-Agder & 2992 & 132 & 133 & 140 & 164 & 172 & $1,29(1,15-1,44)$ \\
\hline Vest-Agder & 4151 & 146 & 119 & 136 & 158 & 140 & $1,18(1,07-1,31)$ \\
\hline Helse Vest & 21795 & 120 & 115 & 121 & 144 & 141 & $1,22(1,17-1,28)$ \\
\hline Rogaland & 8175 & 126 & 118 & 122 & 144 & 135 & $1,13(1,05-1,21)$ \\
\hline Hordaland & 10444 & 108 & 110 & 119 & 142 & 140 & $\begin{array}{c}1,27(1,20- \\
1,35)\end{array}$ \\
\hline
\end{tabular}




\begin{tabular}{|c|c|c|c|c|c|c|c|}
\hline $\begin{array}{l}\text { Regionalt } \\
\text { helseforetak } \\
\text { Fylke }\end{array}$ & $\begin{array}{c}\text { Antall } \\
\text { proteser }\end{array}$ & $\begin{array}{c}1989- \\
1990\end{array}$ & 1991-1995 & $\begin{array}{c}1996- \\
2000\end{array}$ & $\begin{array}{c}2001- \\
2005\end{array}$ & 2006-2008 & $\begin{array}{c}\mathrm{RR}^{2}(95 \% \mathrm{KI}) \\
2006-08 \mathrm{Vs} \\
1991-95\end{array}$ \\
\hline $\begin{array}{l}\text { Sogn og } \\
\text { Fjordane }\end{array}$ & 3176 & 148 & 127 & 127 & 156 & 164 & $1,31(1,17-1,46)$ \\
\hline Helse Midt-Norge & 16824 & 117 & 116 & 118 & 149 & 152 & $1,31(1,25-1,37)$ \\
\hline $\begin{array}{l}\text { Møre og } \\
\text { Romsdal }\end{array}$ & 6315 & 115 & 111 & 110 & 147 & 143 & $\begin{array}{c}1,29(1,19- \\
1,39)\end{array}$ \\
\hline Sør-Trøndelag & 6561 & 116 & 109 & 116 & 141 & 154 & $\begin{array}{c}1,40(1,30- \\
1,51)\end{array}$ \\
\hline Nord-Trøndelag & 3948 & 122 & 139 & 135 & 169 & 165 & $1,19(1,08-1,31)$ \\
\hline Helse Nord & 10092 & 101 & 86 & 104 & 134 & 129 & $\begin{array}{c}1,49(1,40- \\
1,59)\end{array}$ \\
\hline Nordland & 5213 & 93 & 71 & 95 & 135 & 132 & $\begin{array}{c}1,86(1,70- \\
2,04)\end{array}$ \\
\hline Troms & 3488 & 112 & 112 & 123 & 140 & 128 & $1,15(1,03-1,28)$ \\
\hline Finnmark & 1391 & 112 & 91 & 94 & 119 & 116 & $\begin{array}{c}1,28(1,08- \\
1,52)\end{array}$ \\
\hline$[i$ & & & & & & & \\
\hline
\end{tabular}

[i] ${ }^{1}$ Kjønns- og aldersfordeling i Norge i 1989-2008 som standard

${ }^{2}$ Rateratio (RR) justert for kjønn og alder ved Poisson-regresjon

${ }^{3}$ Helse Sør og Helse Øst er behandlet som to regionale helseforetak også etter sammenslåing 1. juni 2007

Selv om forskjellene mellom regionale helseforetak (fig 2) og fylker (tab 2) har avtatt betydelig over tid, er det fortsatt ulikheter. I perioden 2006-08 skilte Helse Midt seg ut med 152 operasjoner per 100 ooo innbyggere ( $\operatorname{tab} 2)$. Dette var statistisk signifikant høyere enn alle andre regionale helseforetak, med unntak av Helse Sør. For fylker var det fortsatt til dels store forskjeller i den siste perioden, også mellom fylker innen samme regionale helseforetak (tab 2).

\section{Diskusjon}

Informasjon om hofteproteseoperasjoner er basert på data rapportert til Nasjonalt register for leddproteser. Data blir meldt direkte fra kirurgen som selv fyller ut skjemaet som sendes til registeret. Dette blir vanligvis gjort like etter operasjonen. Selv om det er frivillig å melde operasjoner til registeret, er det grunn til å tro at registeret har nær komplett registrering. Sammenlikninger gjort med informasjon meldt til Norsk pasientregister (NPR) viser at antall primære hofteproteser meldt til Nasjonalt register for leddproteser utgjorde $97 \%$ av antall proteser meldt til pasientregisteret (21). Den gode rapporteringen er også bekreftet på pasientnivå ved flere sykehus (205)-(207.). Validiteten av meldt informasjon er undersøkt ved ett sykehus og viste meget gode resultater for de undersøkte variablene: side (venstre, høyre), type operasjon (primær, revisjon) og operasjonsdato (25).

Det kan være en svakhet ved studien at bosted var basert på nåværende bosted og ikke hvor man bodde ved operasjonstidspunktet. Med tanke på aktuell aldersgruppe er det likevel

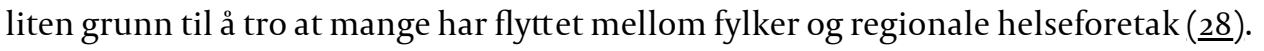


Forekomst av primære hofteproteser på grunn av idiopatisk coxartrose har økt mer enn for totalmaterialet. Dette kan skyldes bedret tilgang til kirurgi, men også en endring av indikasjonsstilling. Det er vist at om man utsetter operasjonen og pasientens tilstand forverres, så blir også utfallet av operasjonen dårligere (욍,30). Dette kan nok i noen grad forklare at man i dag opererer flere unge med antatt mindre smerte og bedre funksjon enn tidligere. Vi fant likevel at $ø$ kningen var sterkest blant de eldste pasientene. Flere eldre med god generell helse og som er i stand til å tåle en hofteproteseoperasjon, bedre anestesi og en generell konsensus om ikke å bruke alder som en kontraindikasjon for operasjon kan forklare denne $ø$ kningen. Det er viktig å unders $\varnothing \mathrm{ke}$ om en slik forandring av indikasjonsstilling vil endre resultatene av hofteprotesekirurgien.

De senere år har vi sett at forekomsten av primære hofteproteser har vært relativt konstant, og man kan stille seg spørsmålet om vi har god nok operasjonskapasitet til å dekke behovet for denne type kirurgi. En studie fra 1999 viste at hofteprotesekirurgien i England var rundt $6 \%$ under behovet (31). Sammenliknbar forekomst av primær hofteprotese er rapportert for Norge og England (32), og om man antar at forekomsten av protesekrevende hoftelidelse også er lik, er det rimelig å tro at heller færre enn for mange får denne type kirurgi i Norge. I mange studier estimeres et $\emptyset$ kende behov for hofteproteseoperasjoner i tiden som kommer som følge av økt andel eldre i befolkningen og som følge av at et økende antall unge (33) og eldre blir operert $(\underline{6}, 33,34)$. Videre studier bør avklare behov for fremtidig operasjonsbehov også for Norge.

Det er vist at forekomsten av primære totale hofteproteser er svært forskjellig i ulike land (4). En studie basert på nasjonale registerdata i årene 1996-200o viste imidlertid at årlig forekomst for protese på grunn av primær coxartrose var relativt lik i de nordiske landene (9.). Det var likevel forskjeller i forekomst for grupper av individer. I samsvar med vår studie observerte Lohmander og medarbeidere (9.) en dobbelt så høy andel med hofteproteser blant norske kvinner sammenliknet med menn, mens forholdet var lavere i de andre nordiske landene: 1,1-1,3.

I likhet med i vår studie er det påvist betydelige regionvise forskjeller i forekomst av primære totale hofteleddsproteser også i andre land (14)-(므). I en dansk studie kunne forskjeller mellom regioner ikke forklares ved ulikheter relatert til diagnose (15). Dette er vanskelig å undersøke i Norge, da prevalens av ulike diagnoser etter bostedsområde generelt er lite kjent. Det er påvist forskjeller i prevalens av coxartrose hos ulike befolkningsgrupper (35,36), og det kan diskuteres om dette delvis kan forklare den lave forekomsten av proteseoperasjoner observert for noen av fylkene. I Oslo per 1. januar 2009 hadde eksempelvis $22 \%$ av befolkningen ikke-vestlig bakgrunn, sammenlignet med $8 \%$ på landsbasis (37.). En annen aktuell forklaring er de holdningmessige forskjellene overfor denne type operasjoner som er påvist for ulike befolkningsgrupper (3ㅁ).

Det er for eksempel vist at ikke-europeiske pasienter har mer plager før de blir operert og at de vurderer en slik operasjon som farligere enn pasienter med europeisk etnisitet (39). Videre har man i studier vist en lavere forekomst av hofteproteser i store byer i land som England, Danmark, Sverige og Finland (14, 15, 17,,4으). Dette er søkt forklart ved at infrastrukturen er bedre og arbeidsforholdene lettere enn i rurale områder, slik at man i større grad kan klare seg uten protese (14). . En studie fra USA viste at lav populasjonstetthet var assosiert med høy hofteproteseforekomst (41), mens andre studier derimot viser at regionale forskjeller ikke kan forklares ved befolkningstetthet og heller ikke av faktorer som tetthet av ortopediske kirurger, sykehuskostnader og regionalt bruttonasjonalprodukt $(14,15,17$.$) . I vår studie har vi ikke justert for faktorer som ulik grad av sykehusdekning og$ operasjonskapasitet, og videre forskning bør undersøke effekten av slike faktorer også for norske forhold. Geografiske forskjeller i indikasjonsstilling for operasjon er også en aktuell forklaringsfaktor for forskjeller i forekomst etter bosted (14.). 
1. Garellick G, Malchau H, Herberts P et al. Life expectancy and cost utility after total hip replacement. Clin Orthop Relat Res 1998; nr. 346:141-51. [PubMed]

2. Laupacis A, Bourne R, Rorabeck C et al. Costs of elective total hip arthroplasty during the first year. Cemented versus noncemented. J Arthroplasty 1994; 9: 481-7. [PubMed] [CrossRef]

3. Hawker GA, Badley EM, Croxford R et al. A population-based nested case-control study of the costs of hip and knee replacement surgery. Med Care 2009; 47: 732-41. [PubMed] [CrossRef]

4. Merx H, Dreinhöfer K, Schräder P et al. International variation in hip replacement rates. Ann Rheum Dis 2003; 62: 222-6. [PubMed] [CrossRef]

5. Fevang BT, Lie SA, Havelin LI et al. Reduction in orthopedic surgery among patients with chronic inflammatory joint disease in Norway, 1994-2004. Arthritis Rheum 2007; 57:529-32. [PubMed] [CrossRef]

6. Pedersen AB, Johnsen SP, Overgaard S et al. Total hip arthroplasty in Denmark: incidence of primary operations and revisions during 1996-2002 and estimated future demands. Acta Orthop 2005; 76:182-9. [PubMed] [CrossRef]

7. Weiss RJ, Stark A, Wick MC et al. Orthopaedic surgery of the lower limbs in 49,802 rheumatoid arthritis patients: results from the Swedish National Inpatient Registry during 1987 to 2001. Ann Rheum Dis 2006; 65:335-41. [PubMed] [CrossRef]

8. da Silva E, Doran MF, Crowson CS et al. Declining use of orthopedic surgery in patients with rheumatoid arthritis? Results of a long-term, population-based assessment. Arthritis Rheum 2003; 49: 216-20. [PubMed] [CrossRef]

9. Lohmander LS, Engesaeter LB, Herberts P et al. Standardized incidence rates of total hip replacement for primary hip osteoarthritis in the 5 Nordic countries: similarities and differences. Acta Orthop 2006; 77: 733-40. [PubMed] [CrossRef]

10. Graves SE, Davidson D, Ingerson L et al. The Australian Orthopaedic Association National Joint Replacement Registry. Med J Aust 2004; 180 (suppl 5): S31-4. [PubMed]

11. Bourne RB, Maloney WJ, Wright JG. An AOA critical issue. The outcome of the outcomes movement. J Bone Joint Surg Am 2004; 86-A: 633-40. [PubMed]

12. Hip and knee replacements in Canada. Canadian Joint Replacement Registry (CJRR) 2008-2009 Annual report. Ottawa: Canadian Institute for Health Information, 2009.

13. Mahomed NN, Barrett JA, Katz JN et al. Rates and outcomes of primary and revision total hip replacement in the United States medicare population. J Bone Joint Surg Am 2003; 85-A: 27-32. [PubMed]

14. Mäkelä KT, Peltola M, Häkkinen U et al. Geographical variation in incidence of primary total hip arthroplasty: a population-based analysis of 34,642 replacements. Arch Orthop Trauma Surg 2010; 130: 633-9.

15. Pedersen AB, Johnsen SP, Overgaard S et al. Regional variation in incidence of primary total hip arthroplasties and revisions in Denmark, 1996-2002. Acta Orthop 2005; 76: 815-22. [PubMed] [CrossRef]

16. Wells VM, Hearn TC, McCaul KA et al. Changing incidence of primary total hip arthroplasty and total knee arthroplasty for primary osteoarthritis. J Arthroplasty 2002; 17: 267-73. [PubMed] [CrossRef]

17. Dixon T, Shaw ME, Dieppe PA. Analysis of regional variation in hip and knee joint replacement rates in England using Hospital Episodes Statistics. Public Health 2006; 120: 83-9o. [PubMed] [CrossRef]

18. Nasjonalt Register for Leddproteser. www.haukeland.no/nrl/ (6.7.2010).

19. Havelin LI, Engesaeter LB, Espehaug B et al. The Norwegian Arthroplasty Register: 11 years and 73,0oo arthroplasties. Acta Orthop Scand 2000; 71:337-53. [PubMed] [CrossRef]

20. Furnes O, Havelin LI, Espehaug B et al. Det norske leddproteseregisteret - 15 nyttige år for pasientene og for helsevesenet. Tidsskr Nor Lægeforen 2003; 123: 1367-9. [PubMed]

21. Espehaug B, Furnes O, Havelin LI et al. Registration completeness in the Norwegian Arthroplasty Register. Acta Orthop 2006; 77: 49-56. [PubMed] [CrossRef]

22. Statistisk sentralbyrå. www.ssb.no/(6.7.2010).

23. Woodward M. Epidemiology. Study design and data analysis. Boca Raton, FL: Chapman \& Hall/CRC, 1999. 
24. National Cancer Institute. Standard populations (millions) for age-adjustment. http://seer.cancer.gov/stdpopulations/(6.7.2010).

25. Arthursson AJ, Furnes O, Espehaug B et al. Validation of data in the Norwegian Arthroplasty Register and the Norwegian Patient Register: 5,134 primary total hip arthroplasties and revisions operated at a single hospital between 1987 and 2003. Acta Orthop 2005; 76: 823-8. [PubMed] [CrossRef]

26. Hulleberg G, Aamodt A, Espehaug B et al. A clinical and radiological 13-year follow-up study of 138 Charnley hip arthroplasties in patients 50-70 years old. Comparison of university hospital data and registry data. Acta Orthop 2008; nr. 5:79.

27. Frøen JF, Lund-Larsen F. Ti år med Lubinus Interplanta hofteproteser. Tidsskr Nor Lægeforen 1998; 118: 2767-71. [PubMed]

28. Statistisk sentralbyrå. Flest flytter innenfor egen kommune. Samfunnsspeilet nr. 5/2005. www.ssb.no/samfunnsspeilet/utg/200505/05/index.html (6.7.2010).

29. Espehaug B, Havelin LI, Engesaeter LB et al. Patient satisfaction and function after primary and revision total hip replacement. Clin Orthop Relat Res 1998; nr. 351: 135-48. [PubMed]

30. Hajat S, Fitzpatrick R, Morris R et al. Does waiting for total hip replacement matter? Prospective cohort study. J Health Serv Res Policy 2002; 7: 19-25. [PubMed] [CrossRef]

31. Frankel S, Eachus J, Pearson $\mathrm{N}$ et al. Population requirement for primary hip-replacement surgery: a cross-sectional study. Lancet 1999; 353: 1304-9. [PubMed] [CrossRef]

32. Flugsrud GB, Nordsletten L, Espehaug B et al. Risk factors for total hip replacement due to primary osteoarthritis: a cohort study in 50,034 persons. Arthritis Rheum 2002; 46: 675-82. [PubMed] [CrossRef]

33. Kurtz SM, Lau E, Ong K et al. Future young patient demand for primary and revision joint replacement: national projections from 2010 to 2030. Clin Orthop Relat Res 2009; 467: 2606-12.

34. Kurtz S, Ong K, Lau E et al. Projections of primary and revision hip and knee arthroplasty in the United States from 2005 to 2030. J Bone Joint Surg Am 2007; 89: 780-5. [PubMed] [CrossRef]

35. Allen KD. Racial and ethnic disparities in osteoarthritis phenotypes. Curr Opin Rheumatol 2010; 22: 528-32. [PubMed] [CrossRef]

36. Nevitt MC, Xu L, Zhang Y et al. Very low prevalence of hip osteoarthritis among Chinese elderly in Beijing, China, compared with whites in the United States: the Beijing osteoarthritis study. Arthritis Rheum 2002; 46:1773-9. [PubMed] [CrossRef]

37. Statistisk sentralbyrå. Innvandrere og norskfødte med innvandrerforeldre, etter landbakgrunn. Fylke. 1 januar 2009. www.ssb.no/emner/02/01/10/innvbef/arkiv/tab-2009-04-30-o9.html (6.7.2010).

38. Hausmann LR, Mor M, Hanusa BH et al. The effect of patient race on total joint replacement recommendations and utilization in the orthopedic setting. J Gen Intern Med 2010; 25: 982-8. [PubMed] [CrossRef]

39. Gandhi R, Razak F, Davey JR et al. Ethnicity and patient's perception of risk in joint replacement surgery. J Rheumatol 2008; 35:1664-7. [PubMed]

40. Söderman P. On the validity of the results from the Swedish National Total Hip Arthroplasty register. Acta Orthop Scand Suppl 2000; 71:1-33. [PubMed] [CrossRef]

41. Peterson MG, Hollenberg JP, Szatrowski TP et al. Geographic variations in the rates of elective total hip and knee arthroplasties among Medicare beneficiaries in the United States. J Bone Joint Surg Am 1992; 74:1530-9. [PubMed]

Publisert: 23. august 2011. Tidsskr Nor Legeforen. DOI: 10.4045/tidsskr.09.1091

Mottatt 11.9. 2009, første revisjon innsendt 31.8. 2010, godkjent 24.3. 2011. Medisinsk redaktør

Are Brean.

(C) Tidsskrift for Den norske legeforening 2023. Lastet ned fra tidsskriftet.no 26. april 2023. 